\title{
And then there were four: A study of UK audit market concentration - causes, consequences and the scope for market adjustment
}

\author{
Vivien Beattie*, Alan Goodacre** and Stella Fearnley***
}

* Professor of Accounting, University of Stirling

** Senior Lecturer in Accounting and Finance, University of Stirling

*** Reader in Accounting, University of Portsmouth

Correspondence details

Professor Vivien Beattie

Department of Accounting, Finance and Law

University of Stirling

Stirling

FK9 4LA

Tel. +44 (0)1786 467306

Fax. $+44(0) 1786467308$

Email V.A.Beattie@ stirling.ac.uk 


\section{And then there were four: A study of UK audit market concentration - causes, consequences and the scope for market adjustment}

\section{AUTHORS' PROFILES}

Vivien Beattie MA(Hons), $\mathrm{CA} \mathrm{PhD}$ is Professor of Accounting in the Department of Accounting, Finance and Law, University of Stirling. She currently holds the part-time appointment of Director of Research of The Institute of Chartered Accountants of Scotland and is a member of the ASB's Academic Panel. Her main research interests are external audit and business reporting.

Alan Goodacre BSc, ACA, PhD is Senior Lecturer in Accounting and Finance in the Department of Accounting, Finance and Law, University of Stirling. His main research interests include leasing, its financial role and accounting treatment, and external audit.

Stella Fearnley BA, FCA is a Reader in Accounting in the Department of Accounting and Management Science, University of Portsmouth and a former senior technical manager in Grant Thornton. She is an elected member of the Council of the Institute of Chartered Accountants in England and Wales and Currently Deputy Chair of its Centre for Business Performance. 


\title{
And then there were four: A study of UK audit market concentration - causes, consequences and the scope for market adjustment
}

\begin{abstract}
While concentration measures are a good indicator of market structure, the link with competitiveness is more complex than often assumed. In particular, the modern theory of industrial organisation makes no clear statement regarding the impact of concentration on competition - the focus of this paper is concentration and no inferences are made about competitive aspects of the market. The extent and nature of concentration within the UK listed company audit market as at April 2002 and, pro forma, after the collapse of Andersens is documented and analysed in detail (by firm, market segment and industry sector). The largest four firms held $90 \%$ of the market (based on audit fees) in 2002, rising to $96 \%$ with the demise of Andersens. A single firm, PricewaterhouseCoopers, held $70 \%$ or more of the share of six out of 38 industry sectors, with a share of $50 \%$ up to $70 \%$ in a further seven sectors. The provision of non-audit services (NAS) by incumbent auditors is also considered. As at April 2002 the average ratio of non-audit fees (paid to auditor) to audit fees was $208 \%$, and exceeded $300 \%$ in seven sectors. It is likely, however, that recent disposals by firms of their management consultancy and outsource firms, combined with the impact of the Smith Report on audit committees will serve to reduce these ratios. Another finding is that audit firms with expertise in a particular sector appeared to earn significantly higher non-audit fees from their audit clients in that sector. The paper thus provides a solid empirical basis for debate. The subsequent discussion considers the implications for companies and audit firms of the high level of concentration in the current regulatory climate, where no direct regulatory intervention is planned.
\end{abstract}

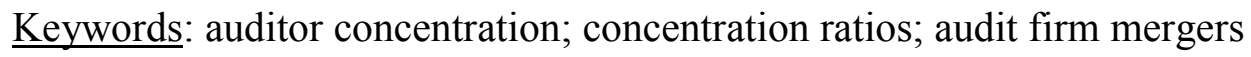




\section{And then there were four: A study of UK audit market concentration - causes, consequences and the scope for market adjustment}

\section{INTRODUCTION}

The last fifteen years have seen the emergence of a dominant Big Eight in the audit market and the subsequent reduction of this group, through merger and firm collapse, to a Big Four. ${ }^{1}$ This group now audits all the FTSE 100 companies in the UK and most other listed companies employ a Big Four firm. The Office of Fair Trading (OFT) found no evidence of anti-competitive behaviour in the UK audit market in a very recent inquiry. Despite this, the high level of market concentration is of concern in the UK, as evidenced by the recommendations of the Coordinating Group on Audit and Accounting and the Treasury Committee in their post-Enron reviews. the final report of the CGAA ${ }^{\text {G }}$ supports the view of the OFT that there is no case for an immediate Competition Commission referral or market referral but that the OFT should keep the market under review. In the US, the hastily enacted Sarbanes-Oxley Act of July 2002 requires the US Comptroller General to study the factors that have led to audit market concentration. These concerns regarding the current level of concentration are heightened by fears that the size of the dominant group could reduce further.

The UK government's basic position is that competitive markets, characterised by many competitors and low barriers to entry, are the main drivers of productivity, efficiency, product development, accurate pricing and choice for the consumer. The competitive process, which may be characterised by concentration, barriers to entry and collusion, is influenced by supply and demand factors, such as costs, incentives, switching costs and information. This process, in turn, influences the nature of market outcomes, such as price and choice. In competition assessment, market share is used as an indicator of the existing level of competition in a market ${ }^{\natural}$ Many academic studies of auditor concentration explicitly offer as motivation the link between market concentration and excessive market power. 
It must be said that concerns about the anti-competitive implications of rising levels of concentration are not new. There has always been a widespread belief that rising concentration leads to anti-competitive behaviour, encouraging tacit or explicit cartellike agreements among the major providers. Yet, paradoxically, during the early 1990 s there were concerns that the large firms were competing too aggressively. ${ }^{6}$ It was widely believed that excessive price competition resulted in 'low-balling' behaviour and cross-subsidisation against non-audit services. In addition, companies perceived a willingness on the part of audit firms to offer different accounting interpretations and this encouraged 'opinion-shopping' behaviour by companies. Although no clear evidence exists to support these beliefs and perceptions, ethical guidance on both matters was issued by the Chartered Accountants Joint Ethics

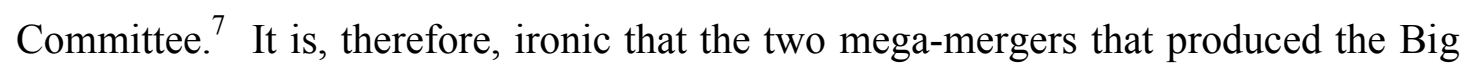
Six in 1989 were a market response to intense competitive pressures.

The most recent reduction in the dominant group, however, arose because of the accounting and auditing scandal associated with Enron. Their auditors, Andersens, suffered reputation loss on such a scale that the firm was unable to continue. This event introduced a shock to the system, destabilising the prevailing market 'equilibrium'. It is argued by some that a consequence of this and other recent accounting scandals has been a marked reduction in audit fee pressures. Companies are no longer pressing for low fees, recognising the need for high quality audit to restore confidence in audited accounts! 9 After a long period of stagnation and even decline in the level of real audit fees in the UK, the US and elsewhere, a widespread step change in audit fees appears to be occurring, at least in the US. The situation in the UK is less clear, as the incidence of audit tendering is increasing and there are no regulatory driven requirements for additional work in relation to corporate governance.

Unfortunately, the debate surrounding these issues is largely based on untested assumptions and anecdotal evidence. The purpose of the present paper is to provide a more solid empirical foundation for the debate. It first reviews the available literature regarding the causes and consequences of audit market concentration, drawing, in particular, upon the modern theory of industrial organisation. Second, it provides systematic empirical evidence on the extent and nature of concentration in the UK 
listed company audit market. In particular, the recent trend in concentration and its level as at April 2002 are reported; this is then disaggregated by firm, by market segment and by FTSE industry sector. The association between non-audit fees paid to the auditor and audit fees is also analysed by firm, market segment and industry sector. The subsequent discussion considers how the market itself may adjust to this high level of concentration in the absence of direct regulatory action.

\section{PRIOR LITERATURE}

\section{Industrial organisation theory}

It is unfortunate that few studies point out the significance of recent developments in industrial organisation theory to studies of audit market concentration and competition. ${ }^{-1}$ Traditional industrial economics holds that market structure (i.e. the numbers of competing firms and their market shares) is a causal determinant of market conduct (i.e. the extent and nature of price and non-price competition). Market conduct, in turn, determines economic performance, in particular, whether or not excess profits are earned through oligopolistic collusion or the exercise of monopoly power. It is belief in this structure-conduct-performance paradigm, in Bain's (1956) traditional formulation, which explains the concerns about rising levels of audit market concentration. 12 Figure 1, panel A shows these simple linkages. A great deal of merger analysis is still based on the analysis of market structure and concentration ratios, perhaps because they are relatively easy to measure. 13

In recent years, however, industrial economists have moved away from claiming that a strict causal relationship exists between concentration and competition. It is argued instead that, in equilibrium, both concentration and performance are jointly determined by underlying cost and demand parameters (Figure 1, panel B) $\stackrel{14}{1}$ Under this view, the detrimental effects of rising concentration are less clear-cut. ${ }^{15}$ Moreover, the 'new industrial organisation' economics has brought strategic issues to the fore, emphasising the importance of barriers to entry and strategic interactions. 6

[Figure 1 about here] 
The modern industrial organisation literature classifies markets into six broad types. Three market types are characterised by high market power and generally ineffective competition: monopoly (one firm has 100\%); dominant firm (one firm has $40 \%$ to 99\%); and tight oligopoly (four firms have over 60\%). The other three market types exhibit effective competition: loose oligopoly (four firms have less than 40\%), monopolistic competition (many competitors each with a slight degree of market power) and pure competition (many competitors, none of whom has market power). 17

\section{Level of concentration in the audit market}

For the audit market, concentration is measured using a variety of metrics, including number of clients, audit fees, and (since audit fees are not publicly disclosed in many countries) surrogates for audit fees such as client revenues or total assets. $\frac{18}{18}$ Concentration ratios, which report the share of a given number of the largest suppliers, are most commonly reported. Comparisons over time and across countries are, however, often difficult due to the different metrics used and the different submarkets analysed.

In virtually all studies, the level of concentration has been shown to be rising over time. In the UK, the four-firm concentration ratio (based on number of audits) for all domestic listed companies (including the USM/AIM) was reported as $43 \%$ in 1987 , $59 \%$ in 1991 and $60 \%$ in 1995.

\section{Causes of change in concentration}

Changes in market concentration occur for three main reasons: voluntary

realignments; changes in the set of consumers; and changes in the set of suppliers. Companies are free to change their auditor, and realignments do take place for a variety of reasons. The six most common reasons given by UK listed companies who changed during the early 1990s were: high audit fee; dissatisfaction with audit quality, in terms of the auditor's ability to detect problems; changes in company's top management; need for group auditor rationalisation; need for a Big Six firm; and merger/takeover by/with another company.21 If, however, there is an underlying preference for the leading suppliers, then these realignments will, ceteris paribus, gradually result in rising concentration. New listings, insolvencies and mergers also play a role, although the overall direction of impact is unpredictable. 
Major increases in concentration can occur when leading suppliers disappear from the market, either through merger or demise. It should be noted, however, that this is not necessarily the case. 22 Various US studies have, however, predicted ex ante or documented ex post an increase in concentration following the Big Eight mergers. 23 It has also been reported that the Big Eight mega-mergers extended the dominance of the large firms across ten countries, particularly in the European market. 24

\section{Consequences of increasing concentration}

A key issue for debate is the extent to which the mega-mergers of recent times have resulted in an increase in market power (reflected in fee levels and audit firm profitability), an increase in efficiency, or a combination of the two effects? In other words, what is the effect on competition? Horizontal mergers tend to increase industry concentration in the face of high barriers to entry and clients' reluctance to change supplier. ${ }^{5}$ This can lead to higher prices. Alternatively, costs may be reduced due to economies of scale and scope, the strategic use of complementary resources, etc. Unfortunately, these are extremely difficult issues to address in a rigorous and comprehensive manner and research in this area is difficult. As one leading industrial economist put it, 'After more than a century of study, [tight oligopoly] continues to baffle and fascinate economists. When a market contains only a few rivals, their behavior, prices, profits, and innovation are difficult to predict. ${ }^{26}$

Several studies examine audit fee trends post-merger. In the UK, there was no significant increase in audit fees post the 1989 mega-mergers, which might be interpreted as a neutral effect on competition. 27 This outcome may, however, have been confounded by over-capacity in the market. One study that set out to explicitly examine the effect of accounting firm mergers on competition in the market for accounting services examined audit firm performance, based on revenue per employee, pre- and post-mergers. ${ }^{8}$ It was found that the performance of large firms did not differ significantly from that of small firms in several countries, suggesting that high levels of concentration do not necessarily mean low levels of competition. Other studies have also concluded that the Big Eight mega-mergers 'may have had little, if any, impact on competition'. 
Another study of the 1989 mega-mergers in the US found that the post-merger period was characterised by a slight decline in market share for the merged firms compared to their close rivals, a decline in audit price for both groups, and a decrease in factor costs for the merged firms relative to their close rivals. This suggests that these mergers resulted in increased efficiencies that were passed through to end users in the

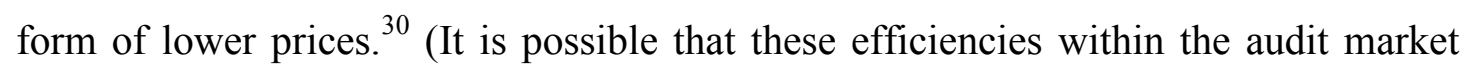
arose due to over-capacity. It is, however, also possible that they were offset by market power influences in non-audit services (NAS).)

Another potentially important consequence of increasing concentration is on the range of supplier choice available. 3 One of the obvious effects of the reduction in the number of top tier audit firms is the reduced choice available. It is known that some companies have a distinct preference for an auditor who is not associated with their competitors. This becomes particularly problematic in concentrated industries where this preference is greater.

\section{Audit market segmentation and industry specialisation}

The market for audit services is recognised to be segmented into distinct sub-markets in a hierarchical way. At the national level, one can distinguish the private (for profit) and public (not-for-profit) sectors, with the former split into listed and unlisted companies. The listed company market can be further split based on (i) stock market indices (e.g. FTSE 100, FTSE 250, Small, Fledgling) and (ii) industry sector. 3

Whether certain types of audit firm seek to specialise in specific stock market sectors is largely unknown (although there is casual evidence to indicate that the top tier firms attach great importance to the reputation-enhancing aspects of auditing a FTSE 100 company). It is, however, widely recognised that the large firms are all specialising in particular industries (product lines) to a degree. They are making huge capital investments in people with industry-specific knowledge and in knowledge management systems to establish the key performance indicators for that industry. $\frac{34}{3}$ Another driver of industry specialism is mergers and acquisitions activity in a sector, since the auditors of the acquirer tend to get the audit of the combined group. US studies have found that concentration levels are highest in regulated industries, in more concentrated industries and in industries experiencing rapid growth, but lower in 
industries with a high risk of litigation. They have also found that industry market leaders gain market share relative to non-leaders, suggesting that there are returns to investing in specialisation.

\section{METHODS}

The database used for the present study covers all companies listed on the London stock exchange (main market and AIM) and their auditors as at April 2002. ${ }^{66}$ The total number of 2,180 companies includes 545 AIM companies and 459 investment trusts. Joint audits were allocated equally to the audit firms concerned.

Market shares are reported using number of audits and audit fees as the activity measures. Since audit fee data was missing for many investment trusts, this sector is excluded from some analyses. While the two measures are very highly correlated, it is known that measures based on the number of clients fall below fee-based measures,

due to the 'size effect', whereby large clients tend to employ large audit firms. Concentration ratios and the number of active firms are also reported.

\section{RESULTS}

\section{Current level and historical trend in UK concentration}

Auditor concentration in the UK domestic listed company market has been documented for at least 35 years. Figure 2 shows the trend in the four- and eight-firm concentration ratios (CR4 and CR8) based on number of audits over this period. A rapid and accelerating increase is apparent. By 2002, immediately prior to the Andersen collapse, CR4 is $66.6 \%$ (including AIM companies and investment trusts) and CR8 is $85.9 \%$ Pro forma figures for 2003, which are calculated on the assumption that all Andersens audits are gained by Deloitte \& Touche (the acquiror of Andersens UK), show a further significant increase in concentration, with the remaining four big firms having $72.8 \%$ of all audits (up $6.2 \%$ from $66.6 \%$ ). CR8 rises to $88.7 \%$. It is interesting to note that the pro forma 2003 Big Four share of the AIM market is only $43.5 \%$. The pro forma data must be viewed as indicative only. It has not been possible to establish whether all audit clients transferred to Deloitte \& Touche. 
[Figure 2 about here]

Population data based on audit fees is available for only a relatively short recent period. It has been reported elsewhere that CR4 excluding investment trusts was $79.4 \%$ in 1995 . 0 The present study shows the corresponding ratio to be $89.6 \%$ in 2002 , with a pro forma of $96.3 \%$ in 2003.40 The exclusion of the AIM companies is unlikely to have a significant impact on these measures, given the relatively low level of audit fees in this sub-market.

Another useful supply-side indicator is the number of firms active in a particular market sector. The dramatic decline is shown in the panel at the foot of Figure 2. In the last twelve years, the number of firms doing audits of domestic listed UK companies has almost halved, dropping from 166 to just 84 .

A more detailed analysis of market shares by individual firm, on the basis of both number of audits and audit fees, is shown in Table 1. This table excludes AIM companies and investment trusts. Several observations can be made from this table. First, the step change in market share between the 'Big Boys' and the rest is now vast. On the basis of audit fees earned, the smallest of the four remaining Big Boys now has $15.6 \%$ of the market (Deloitte \& Touche and Andersens combined market share is 19.2\%), whereas the closest rival is Binder Hamlyn with a mere 1.0\%. Second, the firm with the largest market share, PricewaterhouseCoopers (PwC), now has $36.9 \%$ of the fees in the market. The audit market, commonly characterised as a tight oligopoly, seems to be heading towards what the industrial organisation theorists refer to as a 'dominant firm' market type, with $40 \%$ as the suggested cut-off level. It must be emphasised, however, that the presence of high market share is no longer believed by industrial economists to necessarily lead to anti-competitive behaviour.

[Table 1 about here]

\section{Comparison with the US market}

It is interesting to compare UK concentration levels with those in the US. A recent study covering the three main US exchanges (NYSE, AMEX and NASDAQ) shows 
CR4 based on number of audits to have been $70.4 \%$ in 1999 , possibly just ahead of the corresponding level in the UK at that time.

\section{Concentration by market segment}

An analysis of market shares by market segment, on the basis of audit fees, is shown in Table 2. Each of the main players' shares is also given. A clear pattern emerges of lessening, but still high, concentration levels outside the premier FTSE indices. This pattern is predictable given the 'size effect' discussed above, whereby large companies are associated with large audit firms. It can be noted that in the FTSE 100 sub-market, PwC's market share exceeds the $40 \%$ threshold (measured in terms of both number of audits and audit fees).

\section{[Table 2 about here]}

\section{Concentration by industry sector}

The main market population of 1,635 companies (i.e. including investment trusts but excluding AIM companies) was classified into 38 industry sectors using the two digit sectors from the FTSE Actuaries Industry Classification System and an analysis of market shares by sector, on the basis of audit fees, is shown in Table 3. The number of companies in a sector varies widely from just three (tobacco) to 322 (investment companies) (see column 2 of Table 3 ).

[Table 3 about here]

The Big Five hold 100\% share of six sectors and $\mathrm{PwC}$ audits all three tobacco companies. Specific firms hold market share of $70 \%$ up to $100 \%$ as follows: E\&Y in two sectors (oil and gas; and forestry and paper), KPMG in diversified industrials; and PwC in six sectors (steel and other metals; automobiles; tobacco; gas distribution; water; and insurance). Neither Deloitte \& Touche nor Andersens (nor even the combined firm) achieves this market share in any sector.

Market shares of 50\% up to 70\% are held by Ernst \& Young in one sector (investment companies), KPMG in three sectors (aerospace and defence; beverages; and banks) and PwC in seven sectors (food producers and processors, personal care and 
household products; pharmaceuticals; distributors; general retailers; food and drug retailers; and electricity). Deloitte \& Touche/Andersens combined firm achieves this level of market share in one sector (information technology hardware). Thus, most regulated industries are highly concentrated, consistent with evidence in the US. 43 Below this level of market share, there are many sectors where specialists exist, since a market share of only $15 \%$ is often taken to indicate specialism. 44

\section{Associated non-audit service provision}

One of the major debates to have emerged from the Enron scandal concerns the provision of non-audit services to audit clients, and the effect that this might have (or be seen to have) on auditor independence. ${ }^{45}$ It is, therefore, of interest to compare the ratio of non-audit fees (paid to incumbent auditor) to audit fees for different audit firms and across different market segments and sectors.

\section{[Table 4 about here]}

The average ratio across the entire listed market as at April 2002 is 208\%. Panel A of Table 4 shows how this is skewed towards the top tier firms - the non-Big Five's ratio is only 55\%. Among the Big Five, PwC have the highest ratio (283\%) while Deloitte $\&$ Touche have the lowest (120\%). Panel B shows how the fee ratio varies across market segments. The larger companies in the premier stock market indices have the highest ratio $-271 \%$ for the FTSE 100 falling to $79 \%$ for companies not included in any index. This multiplier effect associated with audit fees is greatest for FTSE 100 companies.

Finally, Panel $\mathrm{C}$ shows the variation in fee ratio within industry sectors. Ratios exceed 500\% for three sectors (food and drug retailers; electricity; and life assurance). Ratios lie between $300 \%$ and $500 \%$ for four sectors (beverages; pharmaceuticals; telecommunication services; and gas distribution). It might be speculated that audit firms with expertise in a particular industry sector (large audit market share) would be more likely to earn higher NAS fees relative to audit fees from audit clients. Given that these firms are likely to have deeper knowledge in these sectors, it is to be expected that they would be among the preferred suppliers. To investigate this, a simple correlation (Pearson coefficient) between fee ratio and sector market share was 
calculated based on the pooled sample of 234 audit firm-sector observations (i.e. 6 audit firms $\times 38$ sectors). The correlation coefficient was found to be positive and highly significant $(\mathrm{r}=0.41 ; \mathrm{p}=0.0001)$ suggesting that increased sector audit market share is associated with a multiplier effect between audit fees and NAS fees from audit clients.

It is likely, however, that recent disposals by firms of their management consultancy and outsource firms, combined with the impact of the Smith Report on audit committees, will serve to reduce these ratios. ${ }^{46}$ The Smith report requires the audit committee 'to develop and implement policy on the engagement of the external auditor to supply non-audit services'.

\section{Discussion}

The results presented above provide a comprehensive view of concentration in the UK domestic listed company audit market as at April 2002.

The extant literature provides very little evidence to justify concerns about a lack of competitiveness resulting from high levels of concentration in the market. However, in the post-Enron environment, there is emerging evidence that, in the US at least, the intense pressure on audit fees has lifted and fees are increasing substantially. By contrast, the amount of NAS purchased from auditors is suggested to be in rapid decline in both the US and the UK. ${ }^{47}$ Although partly due to independence concerns, this may also be partly due to the recent disposals by the large firms of their consultancy arms. These changes have the potential to alter the complex dynamic between concentration and competition in an unpredictable way. Forms of competitive behaviour (both price and non-price) may change.

However, what is certainly true is that the reduction in the number of active audit firms in the market, and especially in the number of top tier firms (now four), does reduce consumer choice and increases the likelihood of conflicts of interest. Companies may find it increasingly difficult (if not impossible) to identify a top tier firm that neither audits nor provides other sensitive services to a major competitor. 
We would argue that, even in the absence of evidence that increasing concentration has undermined competition in the past, the observed current levels of concentration are a legitimate concern. Changing environmental factors mean that past evidence is no longer relevant to the current situation, and reduced choice and conflicts of interest may be growing.

So how could this rise in concentration be halted or reversed? Both demand- and supply-side parameters would need to change. On the demand-side, the pressures to have a top tier auditor are known to be intense. $\frac{48}{4}$ These pressures arise from real or perceived internal needs and from third parties (major shareholders, lenders, bankers and regulators). Until or unless the next tier (the so-called Group A firms) show that they are able, at their current organisation size, to undertake more listed company audits, they will generally not be acceptable suppliers. They may, however, pick up work which the Big Four cannot undertake because of conflicts of interests.

On the supply-side, one possibility is for some of these Group A firms to merge to form a firm that is more comparable in scale to those in the top tier or be a niche supplier of specialist services. A clear problem is the huge chasm of scale (and possibly scope) that separates the top tier firms from the Group A firms. A second possibility is for the existing top tier firms to demerge or otherwise split into smaller organisational units (whether voluntarily or through regulatory intervention). Audits are to some extent divisible, even although joints audits are becoming something of a rarity.

However, it is debatable whether any of these demand- and supply-side changes are possible in practical terms, given the truly global nature of the market and the high barriers to entry. Regulators could, of course, introduce rotation or heavily restrict NAS, but they do not currently appear inclined to do so as a concentration intervention strategy.

\section{SUMMARY AND CONCLUSIONS}

This study provides a detailed analysis of the extent of concentration in the UK listed company market immediately prior to Andersens' demise and, on a pro forma basis, 
the situation in 2003 where only four main players remain. The remaining four firms hold $96 \%$ of the market (based on audit fees), with a single firm (PwC) holding 37\% of the market. Levels of concentration are significantly higher in the premier market segments and certain industry sectors. The multiplier effect between audit fees and NAS fees from audit clients is greatest among FTSE 100 companies and certain industry sectors, while a large sector market share appears to increase the magnitude of this association.

The impact of such high levels of concentration on competition (i.e. the degree of market power and efficiency levels) is difficult to predict, although there is little evidence to suggest that previous increases in concentration have reduced competitiveness in the market. However, the environmental context is changing dramatically - NAS provision to audit clients is falling and this may significantly affect the dynamic between concentration and competition. Moreover, the reduced purchaser choice, exacerbated by conflicts of interest and high barriers to entry to the global market, is problematic.

Four possible market adjustments are considered, although these may be problematic in view of the global nature of the audit market. One demand-side possibility is a change in the attitudes of companies and interested third parties regarding the capability and acceptability of the Group A firms. Supply-side possibilities involve radical organisational change - the merger of group A firms and/or the demerger of the four remaining main players. The fourth possibility is for direct regulatory intervention but the case for this has not been accepted by the OFT or the government. The UK market could also be influenced in the event of regulatory intervention in the US following the findings of the US Comptroller General's study into US market concentration. 
Figure 1: The Structure-Conduct-Performance Paradigm of Industrial Economics

Panel A: Nä̈ve view

Structure

Conduct

Performance

(competitive behaviour)

Panel B: Sophisticated view

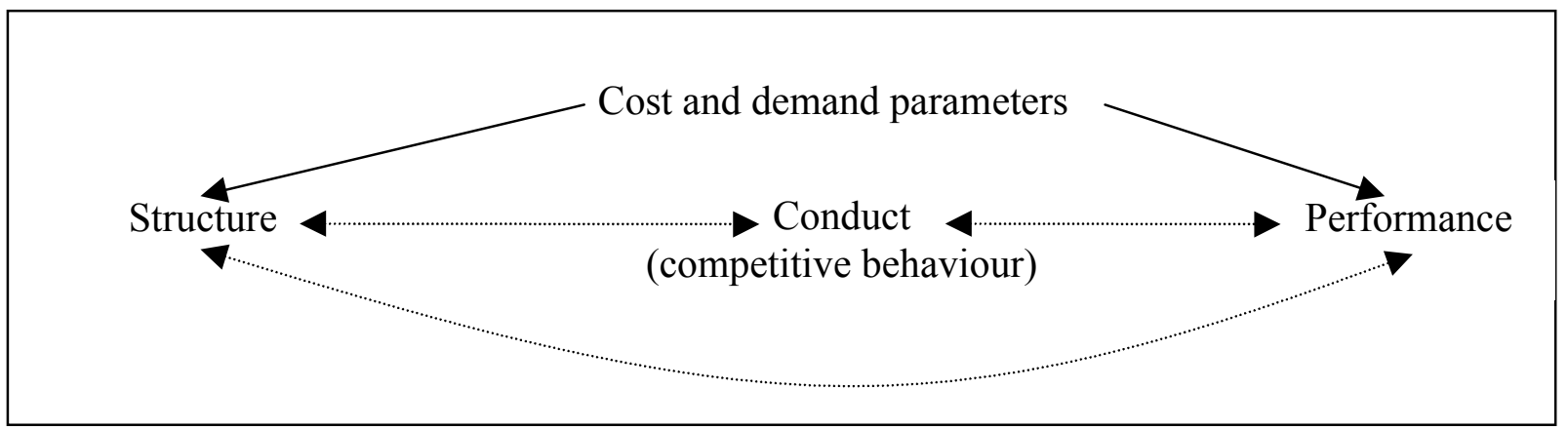


Figure 2: Trend in Concentration in the UK Domestic Listed Company Audit Market

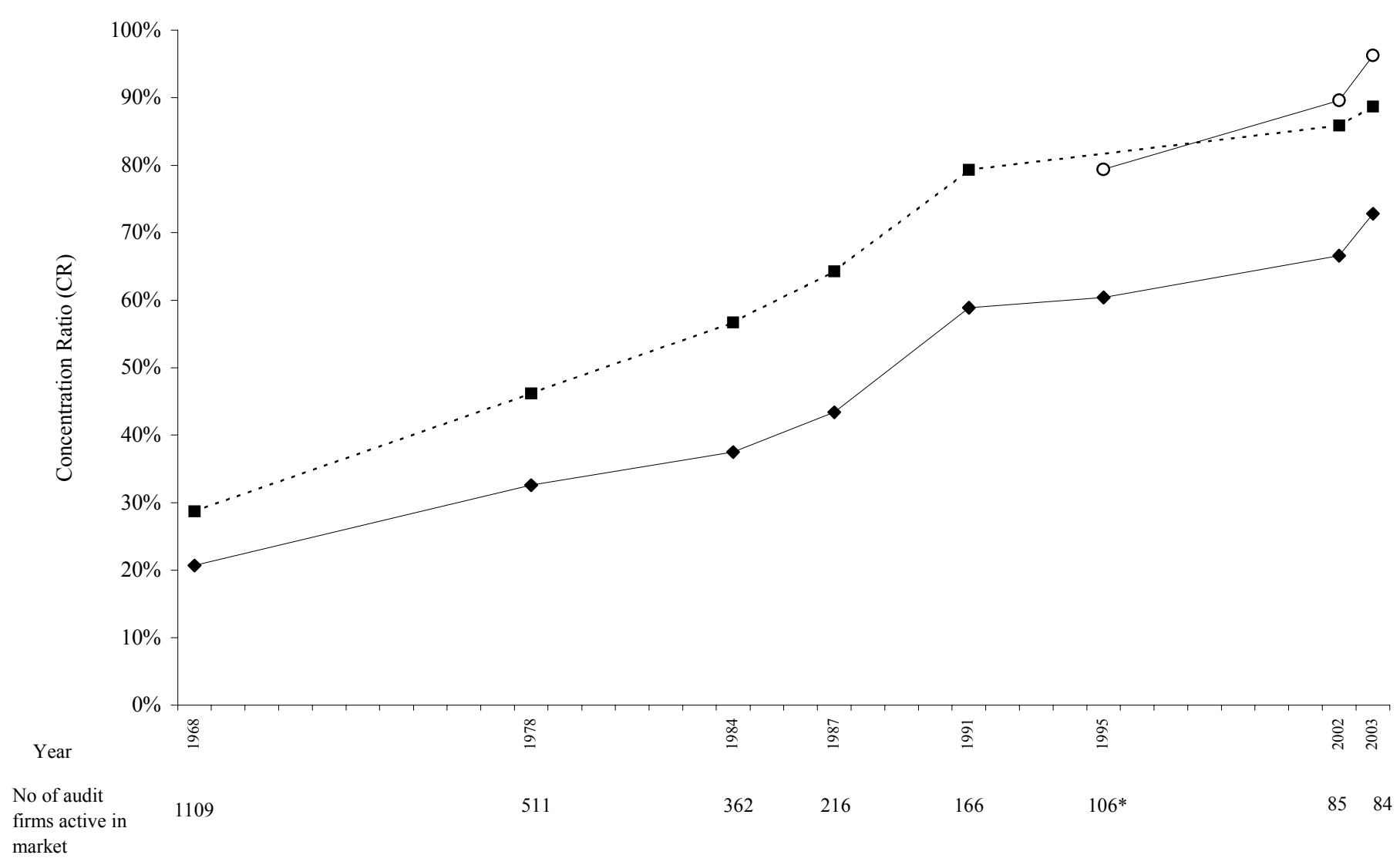

Key: $\quad-\quad$ CR4 based on number of audits (includes AIM companies and investment trusts)

- - $\quad$ CR8 based on number of audits (includes AIM companies and investment trusts)

- - $\quad$ CR4 based on audit fees (excludes AIM companies and investment trusts)

* This figure excludes investment trusts.

Note to figure: Data for 2002 and 2003 (pro forma) are derived using the dataset in the present study. Historical trend data are taken from prior empirical studies. 
Table 1 Auditor market share by individual firm: 2002

\begin{tabular}{|c|c|c|c|c|}
\hline \multirow[b]{2}{*}{ Auditor } & \multicolumn{4}{|c|}{ Market share based on } \\
\hline & \multicolumn{2}{|c|}{ Audit fees } & \multicolumn{2}{|c|}{ No of audits } \\
\hline & Rank & & Rank & \\
\hline PricewaterhouseCoopers & 1 & $36.9 \%$ & 1 & $27.0 \%$ \\
\hline KPMG & 2 & $24.6 \%$ & 2 & $20.7 \%$ \\
\hline Ernst \& Young & 3 & $15.6 \%$ & 4 & $12.9 \%$ \\
\hline Deloitte \& Touche & 4 & $12.5 \%$ & 3 & $13.1 \%$ \\
\hline Andersen & 5 & $6.7 \%$ & 5 & $8.8 \%$ \\
\hline Deloitte \& Touche/Andersen & 3 & $19.2 \%$ & 2 & $22.0 \%$ \\
\hline Total 'Big 5' & & $96.3 \%$ & & $82.6 \%$ \\
\hline BDO Stoy Hayward & 6 & $1.0 \%$ & 7 & $3.4 \%$ \\
\hline Grant Thornton & 7 & $0.8 \%$ & 6 & $3.6 \%$ \\
\hline Baker Tilly & 8 & $0.4 \%$ & 8 & $2.0 \%$ \\
\hline Robson Rhodes & 9 & $0.3 \%$ & 9 & $1.7 \%$ \\
\hline Moore Stephens & 10 & $0.2 \%$ & 12 & $0.4 \%$ \\
\hline PKF & 11 & $0.2 \%$ & 10 & $0.9 \%$ \\
\hline Hacker Young & 12 & $0.1 \%$ & 13 & $0.3 \%$ \\
\hline Horwath Clark Whitehill & 13 & $0.1 \%$ & 11 & $0.6 \%$ \\
\hline Haysmacintyre & 14 & $0.0 \%$ & $14=$ & $0.3 \%$ \\
\hline Chantrey Vellacott & 15 & $0.0 \%$ & $14=$ & $0.3 \%$ \\
\hline Others & & $0.7 \%$ & & $4.0 \%$ \\
\hline Total 'Non-Big 5' & & $3.7 \%$ & & $17.4 \%$ \\
\hline Total: & 57 & $100 \%$ & 57 & $100 \%$ \\
\hline Total audit fees (£m) & & 436.6 & & \\
\hline Number of companies & & 1168 & & 1176 \\
\hline
\end{tabular}

Data used is all listed companies at April 2002 excluding investment companies and AIM companies All auditors with 3 or more audits in 2002 are listed

For 2002, there were 42 'other' auditors, each having 2 audits or less, undertaking a total of 47 audits 
Table 2 Main players' audit market share (based on audit fees) by market segment: 2002

\begin{tabular}{lrrrrrr}
\hline & 100 & 250 & Small & Fledgling & Not Eligible & ALL \\
\hline PricewaterhouseCoopers & & & & & & \\
KPMG & $42.0 \%$ & $32.7 \%$ & $30.4 \%$ & $28.7 \%$ & $35.5 \%$ & $36.9 \%$ \\
Ernst \& Young & $25.4 \%$ & $24.4 \%$ & $27.9 \%$ & $20.0 \%$ & $17.0 \%$ & $24.6 \%$ \\
\hline Deloitte \& Touche & $16.9 \%$ & $13.6 \%$ & $10.9 \%$ & $13.0 \%$ & $27.0 \%$ & $15.6 \%$ \\
Andersen & $11.5 \%$ & $15.7 \%$ & $11.6 \%$ & $11.6 \%$ & $11.5 \%$ & $12.5 \%$ \\
Deloitte \& Touche/Andersen & $4.3 \%$ & $11.4 \%$ & $9.9 \%$ & $6.8 \%$ & $1.0 \%$ & $6.7 \%$ \\
& $15.8 \%$ & $27.1 \%$ & $21.6 \%$ & $18.4 \%$ & $12.5 \%$ & $19.2 \%$ \\
Total 'Big 5' & $100.0 \%$ & $97.8 \%$ & $90.8 \%$ & $80.1 \%$ & $91.9 \%$ & $96.3 \%$ \\
& & & & & & \\
Others & $0.0 \%$ & $2.2 \%$ & $9.2 \%$ & $19.9 \%$ & $8.1 \%$ & $3.7 \%$ \\
Total audit fees (£m) & & & & & & \\
No of observations & 221.9 & 102.2 & 52.6 & 37.4 & 22.5 & 436.6 \\
& 99 & 215 & 284 & 470 & 100 & 1168 \\
\hline
\end{tabular}

Data used is all listed companies at April 2002 excluding investment companies and AIM companies The category 'Not eligible' represents companies that are not eligible for inclusion in the FTSE indices These are usually registered overseas (primarily in Ireland) and cover the whole size spectrum 
Table 3 Main players' audit market share (based on audit fees) by industry sector: 2002

\begin{tabular}{|c|c|c|c|c|c|c|c|c|}
\hline Sector & No of $\cos$ & A & $\mathrm{D} \& \mathrm{~T}$ & $\mathrm{D} \& \mathrm{~T} / \mathrm{A}$ & $\mathrm{E} \& \mathrm{Y}$ & KPMG & $\mathrm{PwC}$ & Big5 \\
\hline \multicolumn{9}{|l|}{ Resources } \\
\hline Mining & 18 & $0 \%$ & $48 \%$ & $49 \%$ & $2 \%$ & $15 \%$ & $33 \%$ & $99 \%$ \\
\hline Oil \& Gas & 28 & $3 \%$ & $0 \%$ & $3 \%$ & $84 \%$ & $2 \%$ & $10 \%$ & $99 \%$ \\
\hline \multicolumn{9}{|l|}{ Basic Industries } \\
\hline Chemicals & 16 & $13 \%$ & $0 \%$ & $13 \%$ & $1 \%$ & $49 \%$ & $34 \%$ & $97 \%$ \\
\hline Construction \& Building Materials & 75 & $6 \%$ & $7 \%$ & $13 \%$ & $20 \%$ & $29 \%$ & $34 \%$ & $96 \%$ \\
\hline Forestry \& Paper & 4 & $0 \%$ & $0 \%$ & $0 \%$ & $74 \%$ & $24 \%$ & $2 \%$ & $100 \%$ \\
\hline Steel \& Other Metals & 7 & $2 \%$ & $3 \%$ & $5 \%$ & $0 \%$ & $0 \%$ & $94 \%$ & $99 \%$ \\
\hline \multicolumn{9}{|l|}{ General Industrials } \\
\hline Aerospace \& Defence & 12 & $1 \%$ & $5 \%$ & $7 \%$ & $1 \%$ & $55 \%$ & $37 \%$ & $100 \%$ \\
\hline Diversified Industrials & 3 & $0 \%$ & $0 \%$ & $0 \%$ & $0 \%$ & $84 \%$ & $0 \%$ & $84 \%$ \\
\hline Electronic \& Electrical Equipment & 42 & $10 \%$ & $3 \%$ & $13 \%$ & $41 \%$ & $14 \%$ & $15 \%$ & $84 \%$ \\
\hline Engineering \& Machinery & 62 & $12 \%$ & $19 \%$ & $30 \%$ & $13 \%$ & $31 \%$ & $22 \%$ & $96 \%$ \\
\hline \multicolumn{9}{|l|}{ Cyclical Consumer Goods } \\
\hline Automobiles & 9 & $12 \%$ & $2 \%$ & $14 \%$ & $0 \%$ & $14 \%$ & $72 \%$ & $99 \%$ \\
\hline Housing Goods \& Textiles & 48 & $4 \%$ & $32 \%$ & $36 \%$ & $11 \%$ & $10 \%$ & $35 \%$ & $92 \%$ \\
\hline \multicolumn{9}{|l|}{ Non-cyclical Consumer Goods } \\
\hline Beverages & 10 & $2 \%$ & $0 \%$ & $2 \%$ & $15 \%$ & $56 \%$ & $25 \%$ & $98 \%$ \\
\hline Food Producers \& Processors & 41 & $11 \%$ & $6 \%$ & $16 \%$ & $4 \%$ & $17 \%$ & $61 \%$ & $99 \%$ \\
\hline Health & 31 & $12 \%$ & $18 \%$ & $30 \%$ & $16 \%$ & $8 \%$ & $44 \%$ & $99 \%$ \\
\hline Personal Care \& Household Prods & 6 & $0 \%$ & $13 \%$ & $13 \%$ & $2 \%$ & $14 \%$ & $67 \%$ & $96 \%$ \\
\hline Pharmaceuticals & 35 & $5 \%$ & $0 \%$ & $5 \%$ & $5 \%$ & $26 \%$ & $62 \%$ & $99 \%$ \\
\hline Tobacco & 3 & $0 \%$ & $0 \%$ & $0 \%$ & $0 \%$ & $0 \%$ & $100 \%$ & $100 \%$ \\
\hline \multicolumn{9}{|l|}{ Cyclical Services } \\
\hline Distributors & 12 & $7 \%$ & $10 \%$ & $17 \%$ & $9 \%$ & $8 \%$ & $59 \%$ & $93 \%$ \\
\hline General Retailers & 68 & $7 \%$ & $9 \%$ & $16 \%$ & $5 \%$ & $15 \%$ & $55 \%$ & $91 \%$ \\
\hline Leisure, Entertainment \& Hotels & 70 & $12 \%$ & $3 \%$ & $14 \%$ & $35 \%$ & $19 \%$ & $22 \%$ & $90 \%$ \\
\hline Media \& Photography & 72 & $20 \%$ & $12 \%$ & $32 \%$ & $12 \%$ & $12 \%$ & $41 \%$ & $97 \%$ \\
\hline Support Services & 102 & $3 \%$ & $23 \%$ & $26 \%$ & $15 \%$ & $23 \%$ & $30 \%$ & $95 \%$ \\
\hline Transport & 39 & $15 \%$ & $12 \%$ & $27 \%$ & $28 \%$ & $17 \%$ & $22 \%$ & $94 \%$ \\
\hline \multicolumn{9}{|l|}{ Non-cyclical Services } \\
\hline Food \& Drug Retailers & 18 & $8 \%$ & $2 \%$ & $10 \%$ & $30 \%$ & $6 \%$ & $\mathbf{5 0 \%}$ & $96 \%$ \\
\hline Telecommunication Services & 18 & $1 \%$ & $28 \%$ & $29 \%$ & $1 \%$ & $30 \%$ & $37 \%$ & $98 \%$ \\
\hline Electricity & 9 & $1 \%$ & $0 \%$ & $1 \%$ & $4 \%$ & $29 \%$ & $67 \%$ & $100 \%$ \\
\hline Gas Distribution & 3 & $0 \%$ & $0 \%$ & $0 \%$ & $0 \%$ & $0 \%$ & $95 \%$ & $95 \%$ \\
\hline Water & 8 & $0 \%$ & $0 \%$ & $0 \%$ & $13 \%$ & $15 \%$ & $70 \%$ & $98 \%$ \\
\hline \multicolumn{9}{|l|}{ Financials } \\
\hline Banks & 16 & $0 \%$ & $19 \%$ & $19 \%$ & $1 \%$ & $55 \%$ & $26 \%$ & $100 \%$ \\
\hline Insurance & 19 & $0 \%$ & $9 \%$ & $9 \%$ & $4 \%$ & $10 \%$ & $74 \%$ & $97 \%$ \\
\hline Life Assurance & 8 & $0 \%$ & $0 \%$ & $0 \%$ & $23 \%$ & $46 \%$ & $31 \%$ & $100 \%$ \\
\hline Investment Companies & 322 & $4 \%$ & $4 \%$ & $8 \%$ & $53 \%$ & $5 \%$ & $28 \%$ & $94 \%$ \\
\hline Real Estate & 65 & $12 \%$ & $17 \%$ & $29 \%$ & $7 \%$ & $21 \%$ & $33 \%$ & $90 \%$ \\
\hline Speciality \& Other Finance & 62 & $12 \%$ & $16 \%$ & $28 \%$ & $5 \%$ & $20 \%$ & $39 \%$ & $92 \%$ \\
\hline Other investment companies & 137 & $0 \%$ & $27 \%$ & $27 \%$ & $13 \%$ & $23 \%$ & $18 \%$ & $81 \%$ \\
\hline \multicolumn{9}{|l|}{ Information Technology } \\
\hline Information Technology Hardware & 30 & $8 \%$ & $43 \%$ & $51 \%$ & $22 \%$ & $2 \%$ & $12 \%$ & $87 \%$ \\
\hline Software \& Computer Services & 107 & $13 \%$ & $19 \%$ & $32 \%$ & $17 \%$ & $18 \%$ & $26 \%$ & $94 \%$ \\
\hline Total number of companies & 1635 & & & & & & & \\
\hline
\end{tabular}

Data used is all listed companies at April 2002 excluding AIM companies

Market shares of $50 \%$ or greater are highlighted in bold

Other investment companies represents venture capital and simliar trusts, all non-eligible for inclusion in FTSE indices 
Table 4 Analysis of non-audit fees paid to auditors: 2002

Panel A: By audit firm

\begin{tabular}{lr}
\hline Auditor & Fee ratio \\
\hline & \\
PricewaterhouseCoopers & $283 \%$ \\
KPMG & $210 \%$ \\
\hline Andersen & $196 \%$ \\
Deloitte \& Touche & $120 \%$ \\
\hline Deloitte \& Touche/Andersen & $146 \%$ \\
Ernst \& Young & $142 \%$ \\
Total 'Big 5' & $214 \%$ \\
& \\
Others & $55 \%$ \\
& \\
Total & $208 \%$ \\
\hline
\end{tabular}

Panel B: By market segment

\begin{tabular}{lcr}
\hline Segment & No of cos & Fee ratio \\
\hline & & \\
100 & 100 & $271 \%$ \\
Small & 250 & $174 \%$ \\
Fledgling & 368 & $129 \%$ \\
Not Eligible & 626 & $116 \%$ \\
& 291 & $79 \%$ \\
ALL & & \\
& 1635 & $208 \%$ \\
\hline
\end{tabular}

Panel C: By industry sector

\begin{tabular}{|c|c|}
\hline Industry Sector & Fee ratio \\
\hline \multicolumn{2}{|l|}{ Resources } \\
\hline Mining & $148 \%$ \\
\hline Oil \& Gas & $190 \%$ \\
\hline \multicolumn{2}{|l|}{ Basic Industries } \\
\hline Chemicals & $148 \%$ \\
\hline Construction \& Building Materials & $99 \%$ \\
\hline Forestry \& Paper & $19 \%$ \\
\hline Steel \& Other Metals & $99 \%$ \\
\hline \multicolumn{2}{|l|}{ General Industrials } \\
\hline Aerospace \& Defence & $247 \%$ \\
\hline Diversified Industrials & $30 \%$ \\
\hline Electronic \& Electrical Equipment & $142 \%$ \\
\hline Engineering \& Machinery & $88 \%$ \\
\hline \multicolumn{2}{|l|}{ Cyclical Consumer Goods } \\
\hline Automobiles & $75 \%$ \\
\hline Housing Goods \& Textiles & $100 \%$ \\
\hline \multicolumn{2}{|l|}{ Non-cyclical Consumer Goods } \\
\hline Beverages & $311 \%$ \\
\hline Food Producers \& Processors & $224 \%$ \\
\hline Health & $106 \%$ \\
\hline Personal Care \& Household Prods & $94 \%$ \\
\hline Pharmaceuticals & $338 \%$ \\
\hline Tobacco & $125 \%$ \\
\hline \multicolumn{2}{|l|}{ Cyclical Services } \\
\hline Distributors & $100 \%$ \\
\hline General Retailers & $198 \%$ \\
\hline Leisure, Entertainment \& Hotels & $205 \%$ \\
\hline Media \& Photography & $284 \%$ \\
\hline Support Services & $142 \%$ \\
\hline Transport & $238 \%$ \\
\hline \multicolumn{2}{|l|}{ Non-cyclical Services } \\
\hline Food \& Drug Retailers & $547 \%$ \\
\hline Telecommunication Services & $395 \%$ \\
\hline Electricity & $672 \%$ \\
\hline Gas Distribution & $411 \%$ \\
\hline Water & $91 \%$ \\
\hline \multicolumn{2}{|l|}{ Financials } \\
\hline Banks & $232 \%$ \\
\hline Insurance & $176 \%$ \\
\hline Life Assurance & $511 \%$ \\
\hline Investment Companies & $84 \%$ \\
\hline Real Estate & $169 \%$ \\
\hline Speciality \& Other Finance & $110 \%$ \\
\hline Other investment companies & $68 \%$ \\
\hline \multicolumn{2}{|l|}{ Information Technology } \\
\hline Information Technology Hardware & $239 \%$ \\
\hline Software \& Computer Services & $135 \%$ \\
\hline
\end{tabular}

Data used is all listed companies at April 2002 excluding AIM companies Fee ratio $=$ total non-audit fees/audit fees

In Panel C, sector fee ratios of greater than $300 \%$ are highlighted in bold 


\section{REFERENCES}

${ }^{1}$ The big eight firms prior to the mergers were: Peat Marwick McLintock (now KPMG); Coopers and Lybrand; Deloitte, Haskins and Sells; Price Waterhouse; Ernst and Whinney; Arthur Young; Touche Ross (now Deloitte and Touche); and Arthur Andersen. In 1989 Ernst \& Whinney merged with Arthur Young to form Ernst \& Young; in 1990 Coopers \& Lybrand merged with Deloitte Haskins \& Sells to form Coopers and Lybrand Deloitte, which merged with Price Waterhouse in 1998 to form PricewaterhouseCoopers. Following the merger of Deloitte and Touche in the US (but not the UK) in 1992, Touche Ross changed its name to Deloitte and Touche in 1996, to provide a single global identity. The demise of Andersens occurred in 2002 and resulted in Deloitte and Touche acquiring Andersens UK.

${ }^{2}$ For example, the interim report of the Coordinating Group on Audit and Accounting (CGAA) issues recommends that the government once again consider the competition implications of these high concentration levels (CGAA, 2002). The Treasury Committee on the Financial Regulation of Public Limited Companies, in its sixth report, specifically recommended that the government consider increasing competition by placing more of its work outside the Big Four (House of Commons, 2002).

${ }^{3}$ CGAA (2003) 'Final Report to the Secretary of State for Trade and Industry and the Chancellor of the Exchequer', January.

${ }^{4}$ Office of Fair Trading, (2002) 'Guidelines for competition assessment', February, London.

${ }^{5}$ For example, Wolk, C.M., Michelson, S.E. and Wootton, C.W. (2001) 'Auditor concentration and market shares in the US: 1988-1999 a descriptive note', British Accounting Review, Vol. 33, No. 2, pp. 157-174.

${ }^{6}$ Financial Reporting Council (1991) 'The state of financial reporting - a review' and Cadbury Committee (1992) 'Committee on the financial aspects of corporate governance'.

${ }^{7}$ Chartered Accountants Joint Ethics Committee (1992a) 'Predatory pricing', Discussion paper, and (1992b) 'Opinion shopping', Draft ethical guidance. The latter has subsequently been incorporated into the ICAEW's Guide to Professional Ethics as Statement 1.213: 'Second and Other Opinions'.

${ }^{8}$ Andersens were found guilty of obstruction of justice in the US resulting from shredding documents relevant to their relationship with Enron.

${ }^{9}$ Goddard, M. (2002) 'The collapse of a house of cards...', Professional Investor, October, pp.14-17.

${ }^{10}$ Goddard, M. (2002) 'The collapse of a house of cards...', Professional Investor, October, pp.14-17.

${ }^{11}$ A notable exception is Beattie, V. and Fearnley, S. (1994) 'The changing structure of the market for audit services in the UK - a descriptive study’, British Accounting Review, Vol. 26, No. 4, pp. 301-322.

${ }^{12}$ Bain, J.S. (1956) 'Barriers to new competition: their character and consequences in manufacturing industries', Harvard University Press, Cambridge.

${ }^{13}$ Office of Fair Trading (1999) 'Quantitative techniques in competition analysis', Research paper 17, October, London, para. 2.36 .

${ }^{14}$ Krouse, C. G. (1990) 'Theory of industrial economics', Basil Blackwell, Oxford.

${ }^{15}$ Farrell, J. and Shapiro, C. (1990) 'Horizontal mergers: an equilibrium analysis', American Economic Review, Vol. 80, pp. 107-126. 
${ }^{16}$ Office of Fair Trading (1999) op. cit., paras. 2.34-2.35.

17 Shepherd, W.G. (1997) 'The economics of industrial organization', $4^{\text {th }}$ edition, Prentice-Hall International, New Jersey, pp. 15-16.

${ }^{18}$ In some cases the square root of these surrogates is used to reduce the bias caused by large clients.

${ }^{19}$ See Beattie and Fearnley (1994) op. cit. and Peel, M.J. (1997) 'UK auditor concentration: a descriptive note', Accounting and Business Research, Vol. 27, No. 4, pp. 311-322.

${ }^{20}$ Beattie and Fearnley (1994) op. cit.

${ }^{21}$ Beattie, V. and Fearnley, S. (1998) 'Audit market competition: auditor changes and the impact of tendering', British Accounting Review, Vol. 30, No. 3, pp. 261-289.

${ }^{22}$ Mueller, D.C. (1985) 'Mergers and market share', Review of Economics and Statistics, May, pp. 259267, cited in Wolk et al. (2001) op. cit, p. 158.

${ }^{23}$ Minyard, D.H. and Tabor, R.H. (1991) 'The effect of big eight mergers on auditor concentration', Accounting Horizons, Vol. 5, No. 4, pp. 79-90 and Tonge, S.G. and Wootton, C.W. (1991) 'Auditor concentration and competition among the large public accounting firms: post-merger status and future implications', Journal of Accounting and Public Policy, Vol. 10, pp. 157-172 examine the proforma impact. Wootton, C.W., Tonge, S.D. and Wolk, C.M. (1994) 'Pre and post big 8 mergers: comparison of auditor concentration', Accounting Horizons, Vol. 8, No. 3, pp. 58-74 and Wolk et al. (2001) op. cit. examine the actual impact ex post.

${ }^{24}$ Choi, M.S. and Zéghal, D. (1999) 'The effect of accounting firm mergers on international markets for accounting services', Journal of International Accounting, Auditing \& Taxation, Vol. 8, No. 1, pp. 1-22.

${ }^{25}$ It is generally believed that the audit market is characterised by high barriers to entry (Ivancevich, S.H. and Zardkoohi, A. (2000) 'An exploratory analysis of the 1989 accounting firm megamergers', Accounting Horizons, Vol. 14, No. 4, pp. 389-401, p. 392 and Choi and Zéghal (1999) op. cit., p. 17) and significant switching costs (Beattie and Fearnley (1998) op. cit., note 4).

${ }^{26}$ Shepherd (1997) op. cit., p.242.

${ }^{27}$ Iyer, V.M. and Iyer, G.S. (1996) 'Effect of big 8 mergers on audit fees: evidence from the United Kingdom' Auditing: A Journal of Practice and Theory, Vol. 15, No. 2, pp. 123-132.

${ }^{28}$ Choi and Zéghal (1999) op.cit.

${ }^{29}$ Minyard and Tabor (1991) op. cit.

${ }^{30}$ Ivancevich and Zardkoohi (2000) op. cit.

${ }^{31}$ Shepherd (1997) op. cit. p.5.

${ }^{32}$ Kwon, S.Y. (1996) 'The impact of competition within the client's industry on the auditor selection decision', Auditing: A Journal of Practice \& Theory, Vol. 15, No. 1, pp. 53-70.

${ }^{33}$ A third split would be into city markets (Francis, J.R., Stokes, D.J. and Anderson, D. (1999) 'City markets as a unit of analysis in audit research and the re-examination of big 6 market shares' Abacus, Vol. 35, No. 2, pp.185-206).

${ }^{34}$ Philip Ashton, BAA Auditing Conference, 1998

35 Hogan, C.E. and Jeter, D.C. (1999) 'Industry specialization by auditors', Auditing: A Journal of Practice \& Theory, Vol. 18, No. 1, pp. 1-17. 
${ }^{36}$ The database of main market companies and their auditors, originally derived from an independent information service, was kindly made available to us by a large audit firm. The data was supplemented, where necessary, with data from the full text accounts of some companies and additional AIM and missing data were extracted from Datastream. The AIM data was extracted from Datastream in February 2003 and so is not precisely time coincident (10 months difference).

${ }^{37}$ See p.120 of Moizer, P. and Turley, S. (1987) 'Surrogates for audit fees in concentration studies', Auditing: A Journal of Practice and Theory, Vol. 7, No. 1, pp. 118-123.

${ }^{38}$ The corresponding ratios excluding investment trusts and AIM companies are slightly higher: CR4 $=$ $73.7 \%$ and $\mathrm{CR} 8=91.8 \%$.

${ }^{39}$ Pong (1999) 'Auditor concentration: a replication and extension for the UK audit market 1991-1995', Journal of Business Finance and Accounting, Vol. 26, No. 3/4, pp. 451-475.

${ }^{40}$ The figures including the 95 investment trusts for which data was available are virtually the same.

${ }^{41}$ Datastream provides audit fee data for 261 of the AIM companies, and the mean audit fee for these is only $£ 34.3 \mathrm{~K}$. This compares with a mean audit fee of $£ 374 \mathrm{~K}$ for main market companies.

${ }^{42}$ Wolk et al. (2002) op. cit., Table 3. The four firms are PwC, Ernst \& Young, Arthur Andersen and KPMG.

${ }^{43}$ Hogan and Jeter (1999) op. cit.

${ }^{44}$ Dunn, K.A., Mayhew, B.W. and Morsfield, S.G. (2000) 'Auditor industry specialization and client disclosure quality' Working paper.

${ }^{45}$ Beattie, V. and Fearnley, S. (2002) Auditor Independence and Non-audit Services: A Literature Review, Institute of Chartered Accountants in England and Wales, London, available at www.icaew.co.uk.

${ }^{46}$ FRC (2003) 'Audit Committees, Combined Code Guidance: A Report and Proposed Guidance', see especially para.2.1 (p.4).

${ }^{47}$ See Fisher, L. (2002) 'Consultancy booms, but tough times ahead', Accountancy, September, pp. 1316; and Parker, A, (2003) 'PwC reveals cut in non-audit fees', Financial Times, February 6, p.25, reports that PwC's UK audit fees have increased by between $10 \%$ and $40 \%$ and the ratio of NAS to audit fees has dropped from $£ 3.30: £ 1$ to $£ 1.40: £ 1$.

${ }^{48}$ Beattie, V. and Fearnley, S. (1995) 'The importance of audit firm characteristics and the drivers of auditor change in UK listed companies', Accounting and Business Research, Vol. 25, No. 100, pp. 227239.

${ }^{49}$ Data for 1968, 1978 and 1984 is taken from Briston, R. and Kedslie, M. (1985) 'Must smaller firms continue to lose out?', Accountancy, March, pp. 163-164; data for 1987 and 1991 is taken from Beattie and Fearnley (1994) op. cit.; data for 1995 is taken from Peel, M.J. (1997) op. cit. (based on number of audits) and Pong, C.K.M. (1999) op. cit (based on audit fees). 